\title{
Cholesterol-lowering potential in human subjects of fat from pigs fed rapeseed oil
}

\author{
Brittmarie Sandström $^{1}$, Susanne Bügel ${ }^{1}$, Charlotte Lauridsen $^{2}$, Flemming Nielsen ${ }^{3}$, \\ Claus Jensen ${ }^{4}$ and Leif H. Skibsted ${ }^{4}$ \\ ${ }^{1}$ Research Department of Human Nutrition and ${ }^{4}$ Department of Dairy and Food Science, \\ The Royal Veterinary and Agricultural University, DK-1958 Frederiksberg C, Denmark \\ ${ }^{2}$ Department of Animal Nutrition and Physiology, Danish Institute of Agricultural Science, DK-8830 Tjele, Denmark \\ ${ }^{3}$ Department of Environmental Medicine, Odense University, DK-5000 Odense C, Denmark
}

(Received 5 July 1999 - Revised 1 December 1999 - Accepted 23 December 1999)

\begin{abstract}
The possibility of achieving blood-lipid-lowering characteristics of pig fat by increasing the content of unsaturated fat in pig feed was evaluated. Three pig feeding regimens were applied: basal feed (no added fat or vitamin E), basal feed + rapeseed oil $(60 \mathrm{~g} / \mathrm{kg}$ feed), and basal feed + rapeseed oil $(60 \mathrm{~g} / \mathrm{kg})+$ vitamin $\mathrm{E}(200 \mathrm{mg} / \mathrm{kg})$. Meat and meat products from the three pig groups were incorporated into diets providing $86 \mathrm{~g}$ pig fat/10 MJ. The diets were served to twelve healthy human male subjects for 3 weeks each in a randomised crossover design. The diets prepared from pigs fed rapeseed oil had a lower content of saturated fatty acids (approximately 9 v. $11 \%$ of energy) and a higher content of polyunsaturated fatty acids (approximately $6 v .4 \%$ of energy) than the diet prepared from pigs fed the basal feed. Diets based on fat from pigs fed the rapeseed oil resulted in significantly lower (approximately $4 \%, P=0.019$ ) total serum cholesterol concentration compared with the diet from pigs fed the basal feed. No differences were observed in LDL-, HDL- or VLDL-cholesterol, or in triacylglycerol or VLDL-triacylglycerol concentrations. Addition of vitamin $\mathrm{E}$ to the pig feed resulted in only a minor increase in vitamin $\mathrm{E}$ content in the human subjects' diet and the vitamin E content was low in all three pig diets. Plasma vitamin $\mathrm{E}$ concentration in the human subjects at the end of the period with diets from pigs fed rapeseed oil without vitamin $\mathrm{E}$ was significantly lower $(P=0.04)$ than in the other two diet periods. In conclusion, an increased content of rapeseed oil in pig feed changes the fatty acid composition of the pig fat in a way that has a potential to reduce blood cholesterol concentrations in human subjects. However, intake of pig fat with a higher content of unsaturated fatty acids needs to be matched by a higher dietary intake of vitamin $\mathrm{E}$.
\end{abstract}

Rapeseed oil: Dietary fatty acids: Blood lipids: Pig feed composition

In industrialised countries animal fats contribute substantially to the total fat intake and are the major sources of saturated fatty acids. Therefore, a low intake of meat has been proposed to reduce the risk of cardiovascular disease (Willett et al. 1995). Since meat contributes essential nutrients such as vitamins and minerals, a reduction in meat intake, while having positive effects in relation to cardiovascular disease, might lead to other nutritional problems. Animal feed strategies and processing technologies could be used to alter product composition to be more consistent with human dietary guidelines. Technologies have been developed to reduce the cholesterol content of animal foods (Labat et al. 1997), and interesterification with polyunsaturated rich oils was shown to improve the fatty acid profile of butter-based spreads (Becker et al. 1999). By increasing the polyunsaturated fatty acid (PUFA) content of cows' feed it is possible to alter the fatty acid composition of beef fat and milk products in a way that improves the blood lipid responses in human subjects consuming diets based on the altered beef fat or milk products (Nestel et al. 1973; Brown et al. 1976; Hodges et al. 1976; Tholstrup et al. 1998).

In ruminants, an increase of unsaturated fatty acids in the feed will have a rather small impact on tissue fatty acid composition, because of microbial hydrogenation of the PUFA and formation of trans fatty acids in the rumen (Brown et al. 1976). In the monogastric pig the fatty acid composition of fat is more closely related to feed fatty acid composition than for other domestic animal species, especially at higher feed fat content (St. John et al. 1987; 
Table 1. Fatty acid composition (\%) of feed, back fat and psoas major phospholipids from pigs fed basal feed or basal feed $+60 \mathrm{~g}$ rapeseed oil $/ \mathrm{kg}$ feed (from Lauridsen et al. 1999a,b)

\begin{tabular}{lccc}
\hline & Saturated fatty acids & $\begin{array}{c}\text { Monounsaturated } \\
\text { fatty acids }\end{array}$ & $\begin{array}{c}\text { Polyunsaturated } \\
\text { fatty acids }\end{array}$ \\
\hline Pigs fed basal diet & 24 & 18 & 59 \\
$\quad$ Feed & 41 & 48 & 11 \\
Back fat & 40 & 54 & 6 \\
$\quad$ Psoas major phospholipids & 12 & 49 & 38 \\
Pigs fed rapeseed oil & 30 & 50 & 19 \\
Feed & 36 & 51 & 13 \\
Back fat & & & \\
Psoas major phospholipids & & & \\
\hline
\end{tabular}

Myer et al. 1992; Jørgensen et al. 1996). Consequently, there is a potential for improvement of the fatty acid composition of pig fat and meat by changes in feed composition.

A potential disadvantage of a more unsaturated animal fat is that the fat becomes more sensitive to oxidation. This could affect the sensoric and storage qualities of the fat and related products. In addition, intake of lipid peroxidation products or a high unsaturated fat intake without concomitant increase in antioxidant intake may increase the risk of oxidative damage in tissues. Oxidation of LDL is believed to be involved in the initiation of atherosclerosis (Steinberg et al. 1989; Berliner \& Heinecke, 1996). Vitamin $\mathrm{E}$ is the major antioxidant in the LDL fraction, and it has been shown to significantly affect the susceptibility of plasma LDL to in vitro oxidation (Dieber-Rotheneder et al. 1991; Princen et al. 1995). Consequently, both from a food quality point of view and regarding the nutritional value, it is important to balance the unsaturated fatty acids with a sufficient content of antioxidants (Dieber-Rotheneder et al. 1991; Bonanome et al. 1992).

The objective of this present study was to evaluate the potential blood lipid lowering effect in man of fat derived from pigs fed a regimen higher in unsaturated fatty acids by addition of rapeseed oil. Furthermore, vitamin $\mathrm{E}$ was added to the pig feed regimen with rapeseed oil and plasma vitamin E concentration in human subjects after intake of the pig fat was evaluated.

\section{Subjects and methods}

\section{Pig feeding regimens}

Female pigs (Danish Landrace $\times$ Danish Yorkshire) were randomly assigned to: (1) basal feed (no added fat or vitamin E); (2) basal feed $+60 \mathrm{~g}$ rapeseed oil $/ \mathrm{kg}$ feed; (3) basal feed $+60 \mathrm{~g}$ rapeseed oil $+200 \mathrm{mg}$ vitamin $\mathrm{E} / \mathrm{kg}$ feed. The animals were given ad libitum access to feed and water from 25 to $100 \mathrm{~kg}$ live weight (slaughter). The composition of the feed and the animal material as well as the raising of animals is described elsewhere (Lauridsen et al. 1999a). In Table 1, fatty acid composition of the pig feed, back fat and intramuscular fat (psoas major) is given for the basal feed group of pigs and the rapeseed oil feed group. The pigs were slaughtered under certified conditions and the meat and fat were used to prepare human diets.

\section{Subjects}

Twelve men (age 24.4 (SD 2.9) years) were recruited for the study. Exclusion criteria were: family disposition for CHD, serum cholesterol $>8 \mathrm{mmol} / \mathrm{l}$, cigarette smoking and high physical activity ( $>6 \mathrm{~h} /$ week). The subjects were all apparently healthy and none of them used any medication. They were allowed to use analgesics if necessary. Height, weight and BMI of the subjects were $182(\mathrm{SD} 8.6) \mathrm{cm}, 72.7$ $(\mathrm{SD} 8.7) \mathrm{kg}$ and $21.8(\mathrm{SD} 1.7) \mathrm{kg} / \mathrm{cm}^{2}$ respectively.

\section{Human study design}

Meat and meat products from three pig-feed treatments were incorporated into daily menus and served for 3 weeks each, in a randomised crossover design. The experimental periods were separated by at least 4 weeks during which the subjects consumed their habitual diets. Blood samples were taken on two consecutive days, before and at the end of each dietary period. Energy intakes were individualised based on age,

Table 2. Example of one day's menu and amount of pork fat naturally occurring or added to the food items

\begin{tabular}{lrr}
\hline & g/10 MJ & $\begin{array}{c}\text { Amount of pork fat naturally } \\
\text { occurring or added (g) }\end{array}$ \\
\hline Breakfast & & 10 \\
$\quad$ Wholewheat bread & 100 & 8 \\
Sausage & 30 & \\
Marmalade & 20 & \\
Orange juice & 250 & 12 \\
Lunch & & \\
Rye bread & 60 & \\
Sausage & 70 & \\
Salad & 100 & 9 \\
Fromage frais & 30 & 9 \\
Apple & 150 & \\
Apple juice & 200 & \\
Snack & & \\
Wholewheat bread & 90 & \\
Sausage & 30 & \\
Cake & 50 & \\
Pear & 150 & \\
Sweets & 30 & \\
Apple juice & 200 & \\
Dinner & & \\
$\quad$ Meat balls & 100 & \\
Curry sauce & 150 & \\
Rice (raw weight) & 60 & \\
\hline
\end{tabular}


body weight and habitual physical activity (World Health Organization, 1985). There were no significant changes in body weight of the subjects during the study period. All foods were weighed on precision scales, and all meals were prepared in individual portions at the department. Breakfast, snacks and weekend meals were prepacked and consumed at home, whereas other meals were consumed at the department under supervision.

\section{Experimental diet}

To assure a constant and homogenous intake of fat and fatty acids, most of the meat and fat was blended to a constant fat content and incorporated into minced-meat dishes, sausages, patés etc. The experimental diet consisted of three daily meals and a snack. Seven different menus were prepared from each pig line with virtually identical nutrient composition. The diets in the three periods were identical, except for the pig group used. An example of one day's menu is given in Table 2. Fat contributed $34 \%$, protein $11 \%$, and carbohydrate $55 \%$ of energy intake. The diets contained $86 \mathrm{~g}$ pig fat $/ 10 \mathrm{MJ}$ contributing $90 \%$ of total fat intake. The content of dietary fibre was $30 \mathrm{~g} / 10 \mathrm{MJ}$. Duplicate portions were taken of each diet in each period and analysed for vitamin $\mathrm{E}$ and fatty acid composition. The analysed fatty acid composition of the diets is given in Table 3.

All foods were prepared in advance in the metabolic kitchen. Individual portions of the meals were weighed according to estimated energy requirements. The individual meals were stored at $-20^{\circ} \mathrm{C}$ after cooking and were thawed and heated on the day of consumption. Lunch and dinner were prepared and served at the department during weekdays. The other meals were provided each day for consumption at home, where thawed meals were heated in a microwave oven provided by the department. Weekend meals were packed and distributed on Friday afternoons. The subjects were instructed not to leave any food, but if they did, they were to bring leftovers back for recording.

\section{Blood sampling}

Venous blood samples were collected after a minimum of $12 \mathrm{~h}$ fasting and $10 \mathrm{~min}$ supine rest. The subjects abstained from alcohol for at least $24 \mathrm{~h}$ and from physical activity for at least $36 \mathrm{~h}$ before sampling.

\section{Analyses}

Blood samples for lipid, lipoprotein and vitamin $\mathrm{E}$ analysis were collected in evacuated tubes with EDTA. Cholesterol and triacylglycerol concentrations in total plasma and lipoprotein fractions were analysed by enzymatic methods (Boehringer Mannheim, Mannheim, Germany) on a Cobas Mira Analyser (Hoffman-La Roche, Basel, Switzerland). Total HDL-cholesterol was measured after precipitation with polyethylene glycol (Quantolip, Immuno AG, Vienna, Austria). LDL-cholesterol was calculated from the difference between total and HDL-cholesterol. The VLDL fraction was separated by ultracentrifugal flotation of fresh plasma $\left(125000 \mathrm{~g}\right.$, for $16 \mathrm{~h}$ at $\left.4^{\circ} \mathrm{C}\right)$ at density $1.006 \mathrm{~g} / \mathrm{l}$ in a Beckman $50 \mathrm{~T}: \mathrm{L}$ rotor (Beckman Instruments, Palo Alto, CA, USA). Precision was determined by analyses of an internal plasma pool. Accuracy was checked by using a Precinorm ${ }^{\circledR}$ L (Lot no. 185597, Boehringer Mannheim $\mathrm{GmbH}$ ). Obtained values for cholesterol and TAG were 5.08 (SD 0.07 ) $\mathrm{mmol} / \mathrm{l}$ and 1.53 (SD $0.03) \mathrm{mmol} / \mathrm{l}(n$ 14) compared with certified values of $5 \cdot 1$ $(4.34-5.87) \mathrm{mmol} / \mathrm{l}$ and $1.69(1.5-2.03) \mathrm{mmol} / \mathrm{l}$ for cholesterol and triacylglycerol respectively.

Total fat in the diets was extracted with light petroleum $\left(40^{\circ}-60^{\circ}\right)$. Composition of fatty acids was determined by GC (HP 6890; Hewlett Packard, Palo Alto, CA, USA) after transesterification to methyl esters in a sodium methylate solution (2g/l methanol). Analysis of the fatty acid methyl esters was carried out using a FFAP column $(25 \mathrm{~m} \times 0.32 \times 0.5 \mu \mathrm{m}$, HP-FFAP, polyethylene glycol, Hewlett Packard) and He as carrier gas with a constant flow of $0.8 \mathrm{ml} / \mathrm{min}$. Injection was split-less with an injector

Table 3. Fatty acid composition of the human subjects' intervention diets*

(Mean values and standard deviations)

\begin{tabular}{|c|c|c|c|c|c|c|c|c|c|}
\hline \multirow[b]{3}{*}{ Fatty acids } & \multicolumn{3}{|c|}{$\begin{array}{l}\text { Diet with fat from pigs } \\
\text { fed basal feed }\end{array}$} & \multicolumn{3}{|c|}{$\begin{array}{l}\text { Diet with fat from pigs } \\
\text { fed basal feed + rapeseed oil }\end{array}$} & \multicolumn{3}{|c|}{$\begin{array}{l}\text { Diet with fat from pigs } \\
\text { fed basal feed + rapeseed oil } \\
\text { and vitamin E }\end{array}$} \\
\hline & \multicolumn{2}{|c|}{$\%$ total fatty acids } & \multirow{2}{*}{$\begin{array}{l}\text { \% of } \\
\text { energy }\end{array}$} & \multicolumn{2}{|c|}{$\%$ total fatty acids } & \multirow{2}{*}{$\begin{array}{l}\text { \% of } \\
\text { energy }\end{array}$} & \multicolumn{2}{|c|}{$\%$ total fatty acids } & \multirow{2}{*}{$\begin{array}{l}\% \text { of } \\
\text { energy }\end{array}$} \\
\hline & Mean & SD & & Mean & SD & & Mean & SD & \\
\hline $16: 0$ & 24 & 0.2 & 7.9 & 19 & 0.3 & $6 \cdot 3$ & 18 & 0.3 & $6 \cdot 0$ \\
\hline $18: 0$ & 13 & 0.2 & $3 \cdot 2$ & 9 & 0.3 & $2 \cdot 2$ & 8 & 0.5 & 2.5 \\
\hline Total saturated & 38 & 0.4 & 11.4 & 30 & 0.5 & 9.5 & 28 & 0.8 & 8.9 \\
\hline $18: 1 n-9$ & 41 & 0.4 & 14.9 & 44 & 0.5 & $15 \cdot 2$ & 45 & 0.6 & $15 \cdot 5$ \\
\hline Total monounsaturated & 45 & 0.5 & $15 \cdot 8$ & 47 & 0.5 & $16 \cdot 1$ & 47 & 0.7 & $16 \cdot 4$ \\
\hline $18: 2 n-6$ & 11 & 0.3 & 3.8 & 15 & 0.4 & 4.7 & 16 & 0.4 & 5.4 \\
\hline Total $n-6$ polyunsaturated & 12 & 0.3 & $4 \cdot 1$ & 16 & 0.4 & $6 \cdot 0$ & 17 & 0.4 & $6 \cdot 3$ \\
\hline $18: 3 n-3$ & $1 \cdot 1$ & 0.02 & 0.4 & $3 \cdot 3$ & 0.05 & 1.2 & $3 \cdot 6$ & 0.1 & 1.4 \\
\hline $22: 5 n-3$ & 0.15 & 0.01 & 0.05 & 0.22 & 0.01 & 0.08 & 0.22 & 0.01 & 0.08 \\
\hline $22: 6 n-3$ & 0.12 & 0.01 & 0.04 & 0.15 & 0.02 & 0.05 & 0.11 & 0.02 & 0.04 \\
\hline Total $n-3$ polyunsaturated & 1.4 & 0.06 & 0.5 & 3.8 & 0.04 & 1.3 & $4 \cdot 1$ & $0 \cdot 11$ & 1.4 \\
\hline Total polyunsaturated & 14 & 0.2 & 4.7 & 20 & 0.5 & $7 \cdot 4$ & 21 & 0.5 & $7 \cdot 8$ \\
\hline
\end{tabular}

\footnotetext{
${ }^{*}$ For details of human subjects' intervention diets see p. 144 and of pigs' diets see Lauridsen et al. $(1999 a, b)$.
} 
temperature of $275^{\circ} \mathrm{C}$. The detector temperature was $300^{\circ} \mathrm{C}$. The initial column temperature was $50^{\circ} \mathrm{C}$, which was held for $2 \mathrm{~min}$. The temperature was then raised at $10^{\circ} \mathrm{C} / \mathrm{min}$ to $240^{\circ} \mathrm{C}$ and this was held for $15 \mathrm{~min}$.

Plasma samples for fatty acid analysis were extracted as described by Bligh \& Dyer (1959), saponified with $0.5 \mathrm{~mol}$ $\mathrm{NaOH} / 1$ methanol, followed by methylation with $2 \mathrm{~mol} \mathrm{BF}_{3} / 1$ methanol and extraction into $n$-heptane. GC analysis (PE 8700; Perkin-Elmer, Norwalk, CT, USA) of the fatty acid methyl esters was carried out using a capillary column (CP Sil 88, $50 \mathrm{~m} \times 0.2 \mathrm{~mm}$ i.d., Chrompack, Middelburg, The Netherlands). He (carrier gas) at a flow rate of $0.5 \mathrm{ml} / \mathrm{min}$ and a $60: 1$ split was used. The temperature was raised from $80^{\circ} \mathrm{C}$ to $160^{\circ} \mathrm{C}$ at a rate of $15^{\circ} \mathrm{C} / \mathrm{min}$, and then increased to $240^{\circ} \mathrm{C}$ at a rate of $3^{\circ} \mathrm{C} / \mathrm{min}$. Fatty acids in both diets and plasma were identified by comparison of retention times with those obtained with a commercial standard $(\mathrm{Nu}$ Check, Elysian, MN, USA). All samples were measured in duplicate.

Vitamin $\mathrm{E}$ in the diet was extracted and quantified by reverse-phase HPLC and fluorescence detection using an external standard (all-rac- $\alpha$-tocopherol, Merck no 115496, Darmstadt, Germany). The CV of the $\alpha$-tocopherol analysis was $1.7 \%$. The mobile phase consisted of methanol-water $(97: 3, \mathrm{v} / \mathrm{v})$ and the HPLC system included a pump (Shimadzu, SIL-10, Kyoto, Japan) set at a flow rate of $1.7 \mathrm{ml} / \mathrm{min}$, a $250 \mathrm{~mm} \times 4.6 \mathrm{~mm}, 5 \mu \mathrm{m} \mathrm{C} 18$ stainless-steel column (Chrompack, Melburg, The Netherlands), an autosampler (Shimadzu, SIL-10) and a fluorescence detector (Waters 470, Milford, MA, USA). Excitation was at $292 \mathrm{~nm}$, emission at $330 \mathrm{~nm}$ and integration was performed by the LC10 software (Shimadzu).

Vitamin $\mathrm{E}$ in plasma was extracted with ethylacetate after addition of internal standard (vitamin A acetate in ethanol, Fluka, Buchs, Switzerland) and protein precipitation with ethanol. Subsequently, vitamin E was quantified by HPLC and fluorescence detection. The mobile phase consisted of methanol-tetrahydrofuran-butanol-water $(85: 5: 5: 5$, by vol) and the HPLC system included a pump (Kontron, Zürich, Switzerland) set at a flow rate of $0.8 \mathrm{ml} / \mathrm{min}$, a $125 \mathrm{~mm} \times 4 \mathrm{~mm}$ C18 stainless-steel column (LiCrospher 100RP-18, Merck, Darmstadt, Germany) an autosampler (Kontron 460, Kontron) and a fluorescence detector (Kontron SFN25, Kontron). Excitation was 340 nm, emission at $460 \mathrm{~nm}$, and integration was performed by Kontron MT-450 software (Kontron). Accuracy of the method was determined by a lyophilised standard reference material $968 \mathrm{~b}$ obtained from the National Institute of Standards and Technology (NIST, Gaithersberg, MD, USA), and the $\mathrm{CV}$ for the vitamin $\mathrm{E}$ analysis was $1.5 \%$.

\section{Ethics}

The subjects were given oral and written information about aims and procedure of the study. The protocol was approved by the Local Research Ethics Committee for Copenhagen and Frederiksberg (KF-01-161/95).

\section{Statistics}

Statistical significance of the difference between means was determined using a mixed model methodology, in the SAS statistical package (Statistical Analysis Systems Inc., Cary, NC, USA; Littell et al. 1996). The mixed model methodology contains both fixed and random effect. A model for ANOVA was used for description of data, where the effect of diet and subject was included in the model. Measurements taken before each intervention were analysed using a one-tailed ANOVA to ensure that there was no carry-over effect. There was no carry-over effect and no period effect and the effect of the diets was evaluated by ANOVA of end values followed by Student's $t$ test for paired data when ANOVA indicated significant differences.

Power calculations $(\alpha=0.05, \beta=0.8)$ showed that with twelve subjects the study would be able to demonstrate a $5 \%$ difference in total plasma cholesterol. Based on available data for present pig fat composition (Møller, 1989) and the expected changes in fatty acid composition it was predicted that the change in plasma cholesterol would be $0.3 \mathrm{mmol} / 1$, i.e. approximately $10 \%$.

\section{Results}

The human diets prepared from pigs fed rapeseed oil had a lower content of saturated fatty acids and a higher content of PUFA than diets prepared from pigs fed the basal feed. The fatty acid composition of the intervention diets (Table 3) closely resembled that of the back fat of the pigs (Table 1). The percentage of monounsaturated fatty acids was virtually identical in the three diets. The content of $\alpha$-linolenic acid in the intervention diets based on fat and meat from pigs fed rapeseed oil was significantly higher than in the diet based on pigs fed basal pig feed. The vitamin E content of the diet with pig meat from the group fed rapeseed oil with added vitamin $\mathrm{E}$ was approximately $30 \%$ higher than that from the other two groups (Table 4). However, due to large variation between the three duplicates the difference was not significant $(P=0 \cdot 08)$.

Intakes of the two diets based on pig fat from pigs fed rapeseed oil resulted in significantly lower (approximately $4 \%)(P=0.03$ and $P=0.001$ respectively) total cholesterol concentrations compared with the diet from pigs fed the basal feed (Table 5). The differences between diets were not significant for any of the other lipoprotein and lipid fractions. Neither was fatty acid composition of plasma at the end of the dietary intervention period different (Table 6).

Table 4. The vitamin E content (mg/10 MJ) of the human subjects' intervention diets*

(Mean values and standard deviations)

\begin{tabular}{|c|c|c|c|c|c|c|}
\hline & \multicolumn{2}{|c|}{$\begin{array}{l}\text { Diet with fat } \\
\text { from pigs } \\
\text { fed basal feed }\end{array}$} & \multicolumn{2}{|c|}{$\begin{array}{l}\text { Diet with fat } \\
\text { from pigs fed } \\
\text { basal feed }+ \\
\text { rapeseed oil }\end{array}$} & \multicolumn{2}{|c|}{$\begin{array}{l}\text { Diet with fat } \\
\text { from pigs fed } \\
\text { basal feed + } \\
\text { rapeseed oil } \\
\text { and vitamin }\end{array}$} \\
\hline & Mean & SD & Mean & SD & Mean & SD \\
\hline $\begin{array}{l}\alpha \text {-Toc } \\
\gamma \text {-Toc }\end{array}$ & $\begin{array}{l}0.7 \dagger \\
0.5 \dagger\end{array}$ & $\begin{array}{l}0.3 \\
0.2\end{array}$ & $\begin{array}{l}0.9 \ddagger \\
0.4 \dagger\end{array}$ & $\begin{array}{l}0.1 \\
0.1\end{array}$ & $\begin{array}{l}1.2 \ddagger \\
0.5 \ddagger\end{array}$ & $\begin{array}{l}0.4 \\
0.1\end{array}$ \\
\hline
\end{tabular}

*For details of human subjects' intervention diets see p. 144 and of pigs' diets see Lauridsen et al. (1999a,b).

$\dagger n 3$.

$\ddagger n 4$. 
Table 5. Blood lipid concentrations ( $\mathrm{mmol} / \mathrm{l}), \alpha$-tocopherol $(\mu \mathrm{mol} / \mathrm{l})$ and $\alpha$-tocopherol : cholesterol ratio $(\mu \mathrm{mol} / \mathrm{mmol})$ at end of each 3-week dietary intervention period*

(Mean values and standard deviations for twelve subjects)

\begin{tabular}{|c|c|c|c|c|c|c|}
\hline & \multicolumn{2}{|c|}{$\begin{array}{c}\text { Diet with } \\
\text { fat from pigs } \\
\text { fed basal feed }\end{array}$} & \multicolumn{2}{|c|}{$\begin{array}{l}\text { Diet with fat } \\
\text { from pigs fed } \\
\text { basal feed }+ \\
\text { rapeseed oil }\end{array}$} & \multicolumn{2}{|c|}{$\begin{array}{l}\text { Diet with fat } \\
\text { from pigs fed } \\
\text { basal feed + } \\
\text { rapeseed oil and } \\
\text { vitamin E }\end{array}$} \\
\hline & Mean & SD & Mean & SD & Mean & SD \\
\hline Total cholesterol & $3.62^{a}$ & 0.58 & $3.47^{\mathrm{b}}$ & 0.57 & $3.44^{b}$ & 0.49 \\
\hline VLDL-cholesterol & 0.18 & 0.11 & $0 \cdot 16$ & 0.08 & 0.18 & 0.12 \\
\hline LDL-cholesterol & $2 \cdot 25$ & 0.50 & $2 \cdot 20$ & 0.55 & $2 \cdot 19$ & 0.56 \\
\hline HDL-cholesterol & 1.19 & 0.25 & $1 \cdot 18$ & 0.25 & $1 \cdot 15$ & 0.25 \\
\hline Total cholesterol: HDL-cholesterol ratio & 3.08 & 0.65 & $3 \cdot 12$ & 0.72 & $3 \cdot 21$ & 0.70 \\
\hline LDL : HDL-cholesterol ratio & 0.54 & 0.08 & 0.50 & 0.06 & 0.48 & 0.04 \\
\hline Total TAG & 0.69 & 0.25 & 0.63 & 0.19 & 0.69 & 0.26 \\
\hline VLDL-TAG & 0.39 & 0.20 & 0.33 & 0.14 & 0.39 & 0.23 \\
\hline HDL- + LDL-TAG & 0.29 & 0.07 & 0.29 & 0.06 & 0.30 & 0.06 \\
\hline$\alpha$-Tocopherol & $18 \cdot 2^{\mathrm{a}}$ & 3.5 & $16 \cdot 9^{b}$ & 3.8 & $17 \cdot 8^{a}$ & $3 \cdot 1$ \\
\hline$\alpha$-Tocopherol : cholesterol ratio & $4 . \overline{9}$ & 4.9 & 4.6 & 0.9 & $5 \cdot 1$ & 0.4 \\
\hline
\end{tabular}

TAG, triacylglycerol.

${ }^{\mathrm{a}, \mathrm{b}}$ Mean values within a row with unlike superscript letters were significantly different: $P<0.05$.

*For details of human subjects intervention diets' see p. 144 and of pigs' diets see Lauridsen et al. (1999a,b).

Plasma $\alpha$-tocopherol concentration and $\alpha$-tocopherol : cholesterol ratio were significantly lower at the end of intervention with diet prepared from pigs fed basal feed with added rapeseed oil compared with diets prepared from pigs fed either the basal feed or rapeseed oil with addition of vitamin $\mathrm{E}(P=0 \cdot 04$; Table 5$)$.

\section{Discussion}

This present study demonstrates that inclusion of rapeseed oil into commercial pig feed alters the fatty acid composition of the pig fat in such a way that, when this fat comprises the major fat source in the diets of human subjects, a slight lowering of blood cholesterol concentrations is achieved. The differences in fatty acid composition between the human diets were smaller than anticipated when planning the study, basing calculations on food table data for pig fat composition (Møller, 1989). The basal pig feed without added fat resulted in a higher content of unsaturated fatty acids in the pig fat than expected from available food table data. When the basal pig feed was supplemented with the monounsaturated rich rapeseed oil, notably the relation between PUFA and saturated fatty acids changed, whereas the content of monounsaturated fatty acids was constant. When rapeseed oil is fed at high levels $(10 \%$ and $20 \%)$, incompatible with other quality

Table 6. Fatty acid profile in plasma as a percentage of total fatty acids $(\mathrm{w} / \mathrm{w})$ at the end of each 3-weeks dietary intervention*

(Mean values and standard deviations for twelve subjects)

\begin{tabular}{|c|c|c|c|c|c|c|}
\hline \multirow[b]{2}{*}{ Fatty acids } & \multicolumn{2}{|c|}{$\begin{array}{l}\text { Diet with fat } \\
\text { from pigs } \\
\text { fed basal feed }\end{array}$} & \multicolumn{2}{|c|}{$\begin{array}{l}\text { Diet with fat } \\
\text { from pigs fed } \\
\text { basal feed }+ \\
\text { rapeseed oil }\end{array}$} & \multicolumn{2}{|c|}{$\begin{array}{l}\text { Diet with fat } \\
\text { from pigs fed } \\
\text { basal feed }+ \\
\text { rapeseed oil and } \\
\text { vitamin } E\end{array}$} \\
\hline & Mean & SD & Mean & SD & Mean & SD \\
\hline $16: 0$ & 25 & 0.8 & 24 & 1.2 & 24 & 0.9 \\
\hline $18: 0$ & 14 & 0.9 & 14 & $1 \cdot 1$ & 15 & 1.0 \\
\hline Total saturated & 40 & 1.0 & 39 & 2.0 & 40 & $1 \cdot 1$ \\
\hline $18: 1$ & 11 & 0.5 & 11 & 1.0 & 11 & 0.9 \\
\hline Total monounsaturated & 12 & 0.6 & 12 & 1.0 & 13 & 0.9 \\
\hline $18: 2 n-6$ & 24 & 2.6 & 25 & $2 \cdot 2$ & 25 & 2.6 \\
\hline $20: 3 n-6$ & 3 & 0.5 & 3 & 0.4 & 3 & 0.4 \\
\hline $20: 4 n-6$ & 11 & 2.0 & 11 & $2 \cdot 0$ & 11 & $2 \cdot 0$ \\
\hline Total $n-6$ fatty acids & 40 & 0.8 & 40 & $1 \cdot 1$ & 40 & 1.3 \\
\hline $18: 3 n-3$ & 0.3 & 0.1 & 0.3 & $0 \cdot 1$ & 0.3 & 0.1 \\
\hline $22: 5 n-3$ & 1 & 0.1 & 1 & 0.1 & 1 & 0.1 \\
\hline $22: 6 n-3$ & 4 & 0.7 & 4 & 0.6 & 4 & 0.7 \\
\hline Total $n-3$ fatty acids & 6 & 0.9 & 7 & 0.9 & 6 & 0.9 \\
\hline Total polyunsaturated & 46 & 0.9 & 47 & 1.4 & 46 & $1 \cdot 1$ \\
\hline
\end{tabular}


characteristics of pig meat, an increase in the relative content of monounsaturated fatty acids is observed ( $\mathrm{St}$ John et al. 1987; Rhee et al. 1988).

Intake of the modified pig fat lowered total cholesterol concentration by $4-5 \%$ in young male subjects compared to pig fat produced by conventional feeding. The observed effect can to a large extent be ascribed to the lower content of saturated fatty acids and a higher content of polyunsaturated $n-6$ fatty acids. No significant differences were observed for the lipoprotein fractions and for the triacylglycerol. The observed effects on total cholesterol were slightly larger than could be predicted from differences in the analysed fatty acid composition. As these predictions (Hegsted et al. 1965; Keys et al. 1965; Yu et al. 1995) are mainly based on studies with vegetable fats, it is possible that the pattern of fatty acids in animal fat affects blood lipids differently. A recent meta-analysis of dietary intervention programmes using the National Cholesterol Education Programme's Step I and Step II diets concludes that for every $1 \%$ decrease in energy consumed as dietary saturated fatty acids, total cholesterol decreases by $0.056 \mathrm{mmol} / \mathrm{l}$ (Yu-Poth et al. 1999). In this study the difference in saturated fatty acid content between the diets was approximately $2 \%$ of energy. The slightly higher difference in total cholesterol at approximately $0.2 \mathrm{mmol} / 1$ can probably be attributed to the strict dietary control. Based on meta-analyses of results from pharmacological and dietary interventions it has been estimated that a reduction of total cholesterol concentrations of $1 \%$ will result in a risk reduction of cardiovascular disease of $2 \%$ (Law et al. 1994). Consequently the observed cholesterol reduction could, if extrapolated to populations, have a risk-reducing impact.

The addition of rapeseed oil to the pig feed increased the $\alpha$-linolenic acid content of the pig fat resulting in intakes of $1.4 \%$ of energy as $n-3$ fatty acids $(3.7 \mathrm{~g} / \mathrm{d})$, corresponding to more than twice the minimum recommended intake (Nordic Council of Ministers, 1996). Thus, pig fat rich in $\alpha$-linolenic acid could also, at lower intakes than in this experimental diet, replace marine fats or $\alpha$-linolenic acid rich oils as a source of essential $n-3$ fatty acids.

However, despite the differences in dietary fatty acid composition, no differences were observed in the plasma content of $\alpha$-linolenic acid or other fatty acids. As $43 \%$ of the test fats were consumed under supervision at the department, this poor relation between dietary and plasma fatty acid composition cannot be attributed to poor compliance. The lack of changes in plasma lipid fatty acid composition may be due to the specific triacylglycol structure of lard with palmitate as the dominating fatty acid in the $s n-2$ position (Small, 1991). The unsaturated fatty acids in the $s n-1$ or $s n-3$ position in lard are thus more prone to be hydrolysed. In rapeseed oil the fatty acid in the $s n-2$ position is more often a $n-6$ or $n-3$ PUFA than would be expected from the overall fatty acid composition of the oil (Kallio \& Currie, 1993) and these fatty acids are consequently more likely to appear in the plasma lipid fractions. In this study the difference between the diets in intake of $18: 3 n-3$ was approximately $0.9 \%$ of energy. When the $18: 3 n-3$ intake was increased by about 2 -fold, obtained by an increased intake of rapeseed oil, the content of $18: 3 n-3$ in plasma cholesterol esters fatty acids was increased by $0.9 \%$ (Valsta et al. 1996). It is possible that the content of $18: 3 n-3$ in the diets was too low to reveal any changes in plasma fatty acids and measurements of the fatty acid composition of cholesterol ester would have better reflected the differences in fatty acid composition between diets in this study.

Addition of $200 \mathrm{mg}$ vitamin E/kg to pig feed has been shown to substantially increase the vitamin $\mathrm{E}$ content of both fat and organ meat in pigs (Morrissey et al. 1996). In our study the addition of vitamin $\mathrm{E}$ to pig feed only marginally increased the vitamin E content of the experimental human diets. As the fat and meat was minced to assure homogeneity it is possible that some of the vitamin $\mathrm{E}$ was lost during preparation of the diets. The total dietary vitamin $\mathrm{E}$ intake was $0 \cdot 7-1.2$ tocopherol equivalent/10 MJ per $\mathrm{d}$ and much lower than the recommended daily intake (8-10 tocopherol equivalent/day) (Nordic Council of Ministers, 1996) and the vitamin E:PUFA ratio was low (0.06-0.07). A vitamin E:PUFA ratio of 0.4 has been suggested as being satisfactory (National Research Council, 1989)

The lower plasma vitamin E concentrations in the period with the diet prepared from pigs fed rapeseed oil without vitamin $E$ suggest an increased need for vitamin $E$ at a higher intake of unsaturated fatty acids from animal sources. In all three periods the plasma vitamin $\mathrm{E}$ concentrations were low compared with reference interval values for Danish people (aged 20-39 years, 16-41 $\mu \mathrm{mol} / \mathrm{l}$ (GF Nielsen, JB Nielsen, HR Andersen and P Grandjean, unpublished results)). The tocopherol:cholesterol ratio was approximately $4 \mu \mathrm{mol} / \mathrm{mmol}$. A value of $2.25 \mu \mathrm{mol} / \mathrm{mmol}$ has been suggested as an indication of biochemical abnormality (Scientific Committee for Food, 1992). It should be noted that the total cholesterol concentrations were low in this group of young adult men. In middle-aged Danish men cholesterol concentrations are typically 1.5-2.0 times higher than in the subjects participating in this study (Sjøl et al. 1991). Thus, in older subjects the test diets may have resulted in much lower $\alpha$-tocopherol:cholesterol ratios. This suggests that an increased content of unsaturated fatty acids in animal products have to be accompanied by dietary advice to increase vitamin $\mathrm{E}$ intake from other sources to reduce the risk for tissue oxidative damage.

The importance of a balance between fatty acid composition and antioxidants has also been demonstrated in meat and meat products. A change towards more unsaturated fatty acids has been found to lead to a higher tendency to lipid oxidation when the meat system is exposed to oxidative stress. Such a high lipid oxidation has been demonstrated for pre-cooked pork, in which antioxidant enzymes are denaturated and inactivated and for pork stored in a high- $\mathrm{O}_{2}$ atmosphere to improve the colour (Jensen et al. 1998). However, addition of $200 \mathrm{mg} \alpha$ tocopherol $/ \mathrm{kg}$ to the feed has been found to counteract the increased tendency to oxidation resulting from addition of $60 \mathrm{~g}$ rapeseed oil/kg feed (Jensen et al. 1997).

In conclusion, an increase of the content of monounsaturated fatty acids in pig feed improved the bloodlipid-lowering potential of food products produced from the pig meat and fat. The vitamin E content of the intervention diets was low and significantly lower plasma $\alpha$-tocopherol 
concentration in human subjects was noted after intake of diets prepared from pigs fed rapeseed oil (without added vitamin E). Thus, the improved fatty acid profile of pork fat with regard to potential effects on blood lipids was counteracted somewhat by a potentially negative effect on antioxidative status.

\section{Acknowledgements}

We thank all the participating subjects for their cooperation and enthusiasm, as well as the dietitian Hanne Jensen, the staff of the metabolic kitchen (Berit Hoielt and her assistants), and the laboratory technicians Hanne Lysdal Petersen and Majbritt Schwaner. This research was funded by the Commission of the European Communities programme Dietox: Dietary treatment and oxidative stability of muscle and meat products: nutritive value, sensory quality and safety (AIR III - CT - 92 - 1577). It does not necessarily reflect its views and in no way anticipates the Commission's future policy in this area.

\section{References}

Becker CC, Lund P, Hølmer G, Jensen H \& Sandström B (1999) Effects of butter oil blends with increased concentrations of stearic, oleic and linolenic acids on blood lipids in young adults. European Journal of Clinical Nutrition 53, 535-541.

Berliner J \& Heinecke J (1996) The role of oxidised lipoproteins in atherogenesis. Free Radicals in Biology and Medicine 20, 707-727.

Bligh EG \& Dyer WJ (1959) A rapid method of total lipid extraction and purification. Canadian Journal of Biochemistry and Physiology 37, 911-917.

Bonanome A, Pagnan A, Biffanti S, Opportuno A, Sorgato F, Dorella M, Maiorino M \& Ursini F (1992) Effect of dietary monounsaturated and polyunsaturated fatty acids on the susceptibility of plasma low density lipoproteins to oxidative modification. Arteriosclerosis and Thrombosis 12, 529-533.

Brown HB, deWolfe VG, Naito HK, Harper WJ \& Palmquist DL (1976) Polyunsaturated meat and dairy products in fat-modified food patterns for hyperlipidemia. Research 69, 235-242.

Dieber-Rotheneder M, Puhl H, Waeg G, Striegl G \& Esterbauer H (1991) Effect of oral supplementation with D- $\alpha$-tocopherol on the vitamin $\mathrm{E}$ content of human low density lipoproteins and resistance to oxidation. Journal of Lipid Research 32, $1325-1332$.

Hegsted DM, McGandy RB, Myers ML \& Stare FJ (1965) Quantitative effects of dietary fat on serum cholesterol in man. American Journal of Clinical Nutrition 17, 281-95.

Hodges RE, Salel AF, Dunkley WL, Zelis R, McDonagh PF, Clifford C, Hobbs RK, Smith LM, Fan A, Mason DT \& Lykke C (1976) Plasma lipid changes in young adult couples consuming polyunsaturated meats and dairy products. American Journal of Clinical Nutrition 28, 1126-1140.

Jensen C, Flensted-Jensen M, Skibsted LH \& Bertelsen G (1998) Development of warmed over flavour in chill stored pre-cooked pork patties in relation to dietary rapeseed oil and vitamin $\mathrm{E}$ supplementation. Zeitschrift für Lebensmittel Untersuchung und Forschung 207, 154-159.

Jensen C, Guidera J, Skovgaard IM, Staun H, Skibsted LH, Jensen SK, Møller AJ, Buckley DJ \& Bertelsen G (1997) Effects of dietary $\alpha$-tocopheryl acetate supplementation on $\alpha$-tocopherol deposition in porcine $m$. psoas major and $m$. longissimus dorsi and on drip loss, colour and lipid stability of pork meat. Meat Science 45, 491-500.
Jørgensen H, Jensen SK \& Eggum BO (1996) The influence of rapeseed oil on digestibility, energy metabolism and tissue fatty acid composition in pigs. Acta Agricultural Scandinavian Animal Science 46, 65-75.

Kallio H \& Currie G (1993) Analysis of low erucic-acid turnip rapeseed oil (brassica-campestris) by negative-ion chemical ionization tandem mass-spectrometry - A method giving information on the fatty-acid composition in positions $s n-2$ and $s n-1 / 3$ of triacylglycerols. Lipids 28, 207-215.

Keys A, Anderson JT \& Grande F (1965) Serum cholesterol response to changes in the diet. IV. Particular saturated fatty acids in the diet. Metabolism 14, 776-787.

Labat JB, Martini MC, Carr TP, Elhard BM, Olson BA, Bergmann SD, Slavin JL, Hayes KC \& Hassel CA (1997) Cholesterollowering effects of modified animal fats in postmenopausal women. Journal of the American College of Nutrition 16, 570-577.

Lauridsen C, Højsgaard S \& Sørensen MT (1999a) Influence of dietary rapeseed oil, vitamin $\mathrm{E}$, and copper on the performance and the antioxidative and oxidative status of pigs. Journal of Animal Science 77, 906-916.

Lauridsen C, Nielsen JH, Henckel P \& Sørensen MT (1999b) Antioxidative and oxidative status in muscles of pigs fed rapeseed oil, vitamin E, and copper. Journal of Animal Science 77, $105-115$.

Law MR, Wald NJ \& Thompson SG (1994) By how much and how quickly does reduction in serum cholesterol concentration lower risk of ischaemic heart disease? British Medical Journal 308, 367-372.

Littell RM, Milliken GA, Stroup WW \& Wolfinger RD (1996) SAS ${ }^{\circledR}$ System for Mixed Models. Cary, NC: SAS Inc.

Morrisey PA, Buckley DJ, Sisk H, Lynch PB \& Sheehy PJA (1996) Uptake of $\alpha$-tocopherol in porcine plasma and tissue. Meat Science 44, 275-283.

Myer RO, Lamkey JW, Walker JH, Brendemuhl JH \& Combs GE (1992) Performance and carcass characteristics of swine when fed diets containing canola oil and added copper to alter the unsaturated: saturated ratio of pork fat. Journal of Animal Science 70, 1417-1423.

Møller A (1989) Food Composition Tables. National Food Agency of Denmark, Publication no. SC3. Søborg, Denmark: NFAD.

National Research Council (1989) Recommended Dietary Allowances, 10th ed. Washington, DC: National Academy Press.

Nestel PJ, Havenstein N, Whyte HM, Scott TJ \& Cook LJ (1973) Lowering of plasma cholesterol and enhanced sterol excretion with the consumption of polyunsaturated ruminant fats. New England Journal of Medicine 288, 379-382.

Nordic Council of Ministers (1996) Nordic Nutrition Recommendations, Scandinavian Journal of Nutrition $\mathbf{4 0 ,}$ 161-165.

Princen HMG, van Duyvenvoorde W, Buytenhek R, van der Laarse A, van Poppel G, Leuven JAG \& van Himsbergh VWM (1995) Supplementation with low doses of vitamin E protects LDL from lipid peroxidation in men and women. Arteriosclerosis and Thrombosis in Vascular Biology 15, 325-333.

Rhee KA, Ziprin YA, Ordonez G \& Bohac CE (1988) Fatty acid profiles of the total lipid and lipid oxidation in pork muscles as affected by canola oil in the animal diet and muscle location. Meat Science 23, 201-210.

Scientific Committee for Food (1993) Nutrient and Energy Intakes for the European Community. Luxembourg: Office for Official Publications of the European Communities.

Sjøl A, Grunnet K \& Schroll M (1991) Secular trends in serum cholesterol, high density lipoproteins and triacylglycerols 1964-1987. International Journal of Epidemiology 20, 105-113. 
Small DM (1991) The effects of glyceride structure on absorption and metabolism. Annual Reviews of Nutrition 11, 413-434.

St John LC, Young CR, Knabe DA, Thompson LD, Schelling GT, Grundy SM \& Smith SB (1987) Fatty acid profiles and sensory and carcass traits of tissues from steers and swine fed an elevated monounsaturated fat diet. Journal of Animal Science 64, 1441-1447.

Steinberg D, Parthasarathy S, Carew TE, Khoo JC \& Witztum JC (1989) Beyond cholesterol. Modifications of low density lipoprotein that increase its atherogenicity. New England Journal of Medicine 320, 915-924.

Tholstrup T, Sandström B, Hermansen JE and Hølmer G (1998) Effect of modified dairy fat on postprandial and fasting plasma lipids and lipoproteins in healthy young men. Lipids 33, 11-21.

Valsta LM, Salminen I, Aro A \& Mutanen M (1996) $\alpha$-Linolenic acid in rapeseed oil partly compensates for the effect of fish restriction on plasma long chain $n-3$ fatty acids. European Journal of Clinical Nutrition 50, 229-235.
Willett WC, Sacks F, Trichopoulou A, Dresher G, Ferro-Luzzi A, Helsing E \& Trichopoulos D (1995) Mediterranean diet pyramid: a cultural model for healthy eating. American Journal of Clinical Nutrition 61, 1402S-1406S.

World Health Organization (1985) Energy and Protein Requirements. Technical Report Series no. 724. Geneva: WHO.

Yu S, Derr J, Etherton TD \& Kris-Etherton PM (1995) Plasma cholesterol-predictive equations demonstrate that stearic acid is neutral and monounsaturated fatty acids are hypocholesterolemic. American Journal of Clinical Nutrition 61, 1129-1139.

Yu-Poth S, Zhao G, Etherton T, Naglak M, Jonnalagadda S \& Kris-Etherton PM (1999) Effects of the National Cholesterol Education Program's Step I and Step II dietary intervention programs on cardiovascular disease risk factors: a meta-analysis. American Journal of Clinical Nutrition 69, 632-646. 